\title{
Genetic Diversity of Prunus necrotic ringspot virus Isolates Within a Cherry Orchard in New York
}

J. E. Oliver, Department of Plant Pathology and Plant-Microbe Biology, Cornell University, New York State Agricultural Experiment Station, Geneva 14456; J. Freer and R. L. Andersen, Department of Horticultural Sciences, Cornell University, New York State Agricultural Experiment Station, Geneva 14456; K. D. Cox, Department of Plant Pathology and Plant-Microbe Biology, Cornell University, New York State Agricultural Experiment Station, Geneva 14456; T. L. Robinson, Department of Horticultural Sciences, Cornell University, New York State Agricultural Experiment Station, Geneva 14456; and M. Fuchs, Department of Plant Pathology and Plant-Microbe Biology, Cornell University, New York State Agricultural Experiment Station, Geneva 14456

\begin{abstract}
Oliver, J. E., Freer, J., Andersen, R. L., Cox, K. D., Robinson, T. L., and Fuchs, M. 2009. Genetic diversity of Prunus necrotic ringspot virus isolates within a cherry orchard in New York. Plant Dis. 93:599-606.

A survey for Prunus necrotic ringspot virus (PNRSV) in an orchard of Prunus cerasus cv. Montmorency and Prunus avium cv. Hedelfingen in New York by enzyme-linked immunosorbent assay indicated an eightfold higher infection rate in sour cherry $(33 \%, 32$ of 96) than in sweet cherry $(4 \%, 6$ of 136) trees. The presence of PNRSV was confirmed by reverse transcription-polymerase chain reaction and amplification of the coat protein $(\mathrm{CP})$ gene in total RNA from infected leaf tissue. Latent infection was prevalent in the majority of trees infected $(87 \%$, 33 of 38), while a few of them exhibited shock symptoms or had severely reduced growth (13\%, 5 of 38). Asymptomatic PNRSV-infected trees clustered in spatial proximity to symptomatic trees. Sequence analysis of the CP gene $(675 \mathrm{bp})$ indicated a population structure consisting of one predominant molecular variant for 10 isolates and six minor molecular variants for seven isolates. A high sequence identity was found between the CP gene of PNRSV isolates from cherry trees and other isolates from diverse hosts and various geographic origins at the nucleotide and amino acid levels ( 88 to $100 \%$ ). Phylogenetic analyses showed a clustering of PNRSV isolates from cherry trees in New York in the predominant group PV-96.
\end{abstract}

Prunus necrotic ringspot virus (PNRSV) causes serious losses worldwide to cultivated Prunus spp., including cherry, peach, apricot, nectarine, plum, and almond. Reduced vigor (up to $30 \%$ ), yield (20 to $56 \%$ ), and fruit quality have been reported in infected trees $(24,28,33)$. In cherry, PNRSV symptomatology can be latent or consist of foliar mosaics, rings, or chlorotic areas that may develop into severe necrotic spots with a shot hole appearance. The latter symptoms are referred to as shock syndrome $(20,25)$. PNRSV can also infect ornamentals, including roses (22,35).

PNRSV belongs to the genus Ilarvirus in the family Bromoviridae (18). The viral genome is tripartite and consists of singlestranded positive-sense RNAs. Replicative functions are encoded by RNA1 and RNA2, while RNA3, which is bicistronic, encodes the movement and coat protein

\section{Corresponding author: M. Fuchs}

E-mail:mf13@cornell.edu

Accepted for publication 17 February 2009.

doi:10.1094/PDIS-93-6-0599

(C) 2009 The American Phytopathological Society subgenomic RNA called RNA4 (5). No arthropod, nematode, plasmodiophorid, or fungus vector is known for PNRSV. Instead, the virus spreads readily through budding and grafting (17). It is also seedand pollen-borne by the wind, pollinator insects, and sucking insects $(17,19)$.

Many isolates of PNRSV with diverse biological properties have been identified $(6,13,14,22)$. Also, distinct serogroups of PNRSV have been characterized with polyclonal antisera and monoclonal antibodies (20-23,30). The sequence of RNA3, including the CP gene, has been determined for numerous isolates, and phylogenetic analyses have revealed a clustering of PNRSV isolates into three major groups, including PV-32, PE-5, and PV-96 (3,13,29,34). An additional phylogroup named $\mathrm{CH} 30$ was recently proposed (12).

Reports from the early 1960s documented the occurrence of PNRSV in New York, especially in sour (Prunus cerasus L.) and sweet (Prunus avium L.) cherry trees $(1,2,10)$, as well as in cherry rootstocks (11). PNRSV was also described in rose in New York in the late 1980s (34). However, no information is available on the genetic variability of PNRSV isolates from New York. Similarly, little is known on the population structure of PNRSV isolates within an infected Prunus orchard. The objectives of our study were to (i) determine the incidence of PNRSV in an experimental orchard of sour ( $P$. cerasus $\mathrm{cv}$. Montmorency) and sweet (P. avium cv. Hedelfingen) cherry in which a few trees $(2 \%, 5$ of 232) exhibited typical shock symptoms in the spring of 2006, and (ii) provide some insights into the population structure and genetic diversity of PNRSV isolates. Individual trees were surveyed over two consecutive years for PNRSV by double antibody sandwich-enzyme-linked immunosorbent assay (DAS-ELISA), and the CP gene of infecting isolates was characterized by reverse transcriptionpolymerase chain reaction (RT-PCR) and sequencing. We report here a higher incidence of PNRSV in sour cherry trees versus sweet cherry trees over the 2-year period of our study, and a clustering of these New York isolates into the predominant phylogenetic group PV-96.

\section{MATERIALS AND METHODS}

Cherry orchard and leaf sample collection. The cherry orchard surveyed in this study was an 8-year-old rootstock trial block established on the Research North Farm at the New York State Agricultural Experiment Station (NYSAES), Cornell University, Geneva.

Test trees consisted of $P$. cerasus cv. Montmorency and P. avium cv. Hedelfingen grafted onto dwarfing, semi-dwarfing, or full vigor rootstocks, including $P$. cerasus $\times$ P. canescens cvs. Gisela 3, Gisela 4, Gisela 5, Gisela 6, Gisela 7, Gisela 195/20, P. cerasus L. (Tabel Edabriz), P. cerasus L. (Weiroot 10, 13, 53, 72, and 158), and $P$. mahaleb L. (Mahaleb). For Hedelfingen, the full vigor rootstock $P$. avium L. (Mazzard) was also used. Replicates of eight trees were planted for most cultivar/rootstock combinations in a split-plot complete block design with random replicate allocation within blocks. A few $P$. avium cv. Hedelfingen trees were also on rootstocks $\mathrm{P} 50, P$. avium $\times P$. cerasus $(\mathrm{P}-$ HL-A), and $P$. mahaleb L. (Mahaleb). Trees were planted in four rows of 65 trees 
each, spaced $4.5 \mathrm{~m}$ apart within rows and $6.0 \mathrm{~m}$ between rows.

For high pollination rates of $P$. avium cv. Hedelfingen, compatible $P$. avium cultivars (i.e., Black Gold, Vandalay, and Emperor Francis) were planted in adjacent rows as pollenizers. Also, honey bee and bumble bee colonies were placed in the orchard before and during bloom.

Leaf samples (10 to 12 per tree) were collected for PNRSV detection by DASELISA in June 2006. Young leaves (2 to 5 per twig) were collected from the yearly growth at the tip of lower branches. Alternatively, in May 2007, young leaf tissue was collected from budwood that was removed prior to bloom from selected trees in the orchard and forced in a greenhouse, and was subsequently used for PNRSV detection by DAS-ELISA and RT-PCR. We considered a PNRSV isolate as a viral culture from a single tree. A few trees were also assayed for Prune dwarf virus (PDV) by DAS-ELISA in 2006.

Virus detection by DAS-ELISA. PNRSV and PDV were detected by DASELISA in crude leaf extracts with specific antibodies (Bioreba, Reinach, Switzerland). A portion of 10 to 12 stacked leaves was torn and ground in $200 \mathrm{mM}$ Tris- $\mathrm{HCl}$, $\mathrm{pH} 8.2,140 \mathrm{mM} \mathrm{NaCl}, 2 \%$ polyvinylpyrrolidone 40 , and $0.05 \%$ Tween 20 at a $1: 5$ ratio (wt/vol) using a semi-automated ballbearing HOMEX tissue homogenizer (Bioreba). Test conditions were according to the manufacturer's instructions (Bioreba). Substrate hydrolysis was recorded at 405 nm with an absorbance BioTek ELx808 microplate reader (BioTek, Winooski, VT). Samples were considered positive if their optical density $\left(\mathrm{OD}_{405 \mathrm{~nm}}\right)$ readings were at least twice those of healthy controls $\pm 20 \%$. PNRSV incidence determined by DASELISA was subject to analysis of variance (ANOVA) for a split-plot design using the General Linear Model (GLM) procedure of SAS (version 9.13; SAS Institute Inc., Cary, MC). All percentage data were subject to arcsine square root transformation prior to analysis.

Spatial distribution analysis of PNRSV-infected cherry trees in the experimental orchard. The spatial distribution of shot hole symptom development in
2006 and cumulated DAS-ELISA scores in 2006 and 2007 were mapped using the three dimensional contour mapping feature of Sigmaplot version 9.0 with a scatterplot overlay (Systat Software, Inc., San Jose, CA). Contour maps indicate the location of symptomatic trees by coordinates $\mathrm{x}, \mathrm{y}$, and $\mathrm{z}$, with the $\mathrm{x}$-axis being the row number, the $y$-axis being the within-row location (e.g., tree number), and the z-axis being the type of cherry tree. The scatterplot overlay indicates PNRSV symptoms and/or DAS-ELISA scores for each tree by color and shape, respectively.

Virus detection by RT-PCR. PNRSV was detected by RT-PCR in total RNA from leaf samples of sour and sweet cherry trees that tested positive in DAS-ELISA in 2007. For RNA extraction, leaf tissue (100 $\mathrm{mg}$ ) was placed in a $2.0-\mathrm{ml}$ microfuge tube, dipped in liquid nitrogen, and disrupted with a TissueLyser homogenizer (Qiagen, Valencia, CA) for $2 \mathrm{~min}$ at 30 $\mathrm{MHz}$ in the presence of one stainless steel bead (5 $\mathrm{mm}$ diameter). Total RNA was extracted from homogenized leaf material using the RNeasy Mini Plant Kit (Qiagen).

The PNRSV full-length $\mathrm{CP}$ gene was characterized by RT-PCR using primers described previously (4). In addition, a primer pair specific to the 1,5bisphosphate carboxylase chloroplast gene $(\mathrm{Rbcl})$ of $P$. persica (GenBank accession no. AF206813) was used in standard and multiplex RT-PCR to assess the quality of total RNA preparations and evaluate the effectiveness of the detection assay (27).

One-step RT-PCR was carried out using the Access System (Promega, Madison, WI) with Avian myeloblastosis virus RTase, Tfl DNA polymerase, and 50 pmoles of specific primers in a $50-\mu$ l final volume according to the manufacturer's protocol. Single-tube RT-PCR used a 45min heating step at $45^{\circ} \mathrm{C}$ and a 2 -min heating step at $94^{\circ} \mathrm{C}$ followed by 45 cycles of 1 min melting at $94^{\circ} \mathrm{C}, 1 \mathrm{~min}$ annealing at $55^{\circ} \mathrm{C}$, and 2 min elongation at $68^{\circ} \mathrm{C}$ with a final extension of $7 \mathrm{~min}$ at $68^{\circ} \mathrm{C}$. The reaction products were resolved by electrophoresis in $1.5 \%$ agarose gels in $90 \mathrm{mM}$ Trisborate, $2 \mathrm{mM}$ EDTA, $\mathrm{pH} 8.0$, stained with ethidium bromide, and subsequently visualized under UV light.
Viral sequence determination and analysis. DNA amplicons of the PNRSV CP gene obtained by RT-PCR were extracted from agarose gels with the QIAquick Gel Extraction Kit (Qiagen) and sequenced bidirectionally using the Big Dye Terminator Kit, AmpliTaq-FS DNA polymerase, and an Applied Biosystem Automated 3730xl DNA Analyzer at the Cornell University DNA Sequencing Facility in Ithaca, NY. Sequences were analyzed and compared using the DNASTAR Lasergene v7.2 software package. The program CLUSTAL W was used for alignment of nucleotide sequences (31). Phylogenetic relationships were determined with the neighbor-joining method (26) using PNRSV isolate PE-5 (GenBank accession no. L38823) from peach, isolate PV-32 (GenBank accession no. U03857) from apple, isolate PV-96 (GenBank accession no. S78312) from P. mahaleb, and isolates CH30 (GenBank accession no. AF034994) or SW6 (GenBank accession no. AF013287) from sweet cherry as representative of their respective phylogenetic groups. The robustness of the inferred evolutionary relationships was assessed by 1,000 bootstrap replicates. The algorithm SISCAN (9) was used to confirm the occurrence of recombination events suspected by phylogenetic analysis and sequence alignments.

\section{RESULTS}

Typical PNRSV shock symptoms, i.e., leaf necrosis and shot holing (Fig. 1A), were observed on a limited number of trees $(2 \%, 5$ of 232) in an 8-year-old experimental cherry orchard on the Research North Farm at NYSAES, Geneva, NY in the spring of 2006. New leaves that developed later in the season remained symptomless. Delayed budbreak, retarded bloom, death of leaf and flower buds, slow fruit set, and reduced vigor (Fig. $1 \mathrm{~B}$ and $\mathrm{C}$ ) were also early indications of the shock syndrome induced by PNRSV. Symptomatic trees were all sour cherry. They were located in the southwest corner (row 1 , tree 11, and row 2, trees 7 and 15), north-central area (row 2, tree 46), and northeast corner (row 3, tree 56) of the orchard (Fig. 2).
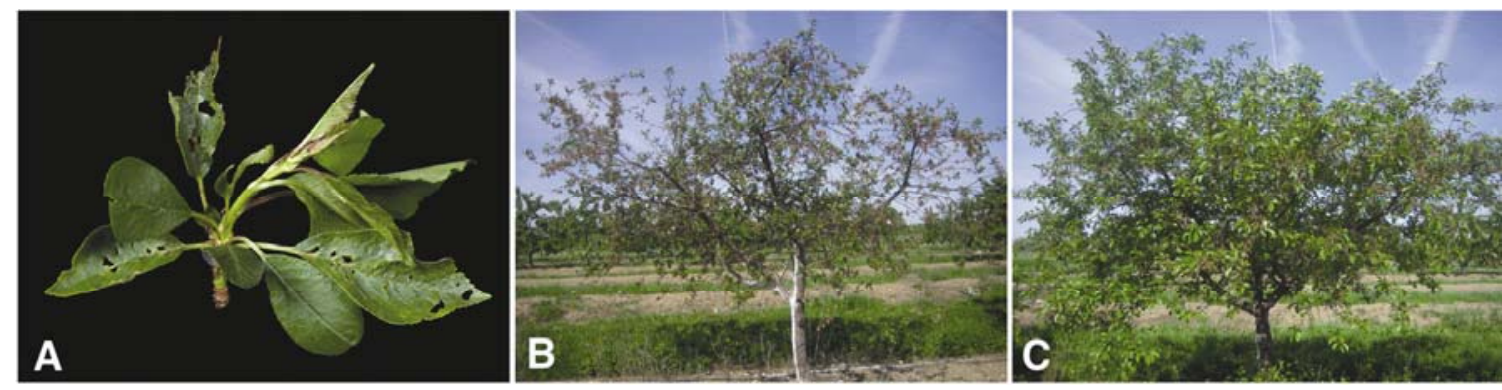

Fig. 1. Reaction of Prunus cerasus cv. Montmorency to Prunus necrotic ringspot virus (PNRSV) infection. A, Foliar necrotic spot and shot holes, and B, differential leaf and flower bud development and reduced vigor of a PNRSV-infected tree in comparison to $\mathbf{C}$, a healthy tree. 


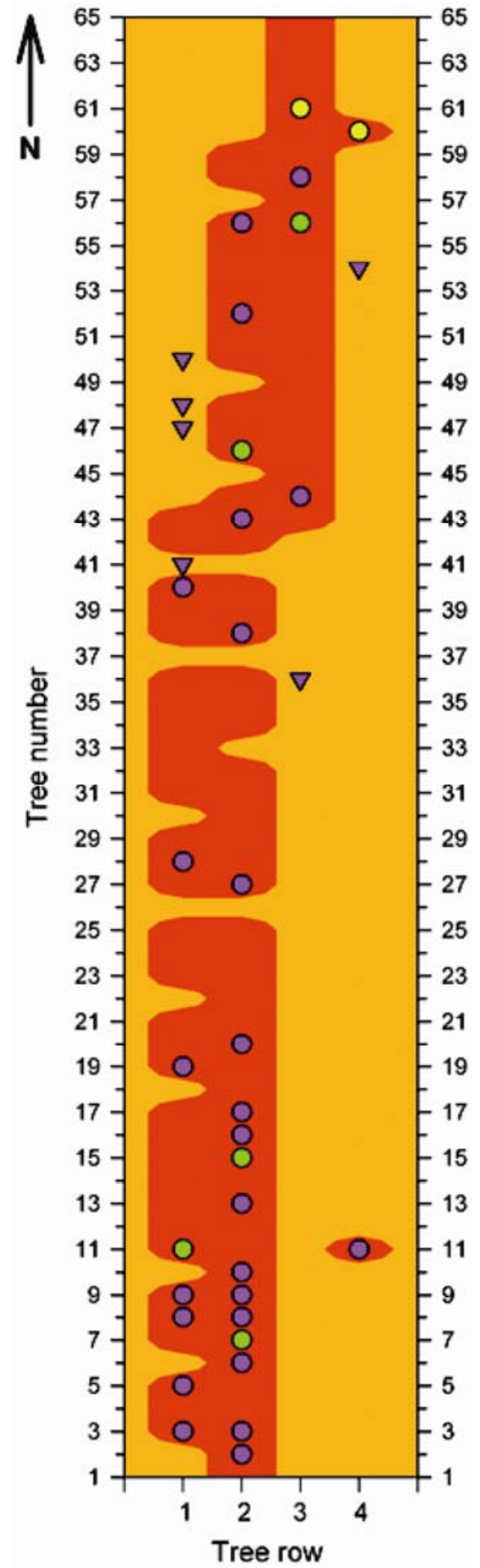

Fig. 2. Spatial distribution of Prunus necrotic ringspot virus (PNRSV)-infected cherry trees in the experimental orchard surveyed. Tree rows are indicated on the $\mathrm{x}$-axis and tree numbers are indicated on the y-axis. Sour cherry trees showing shot hole symptoms in 2006 are represented by green circles. Sweet and sour cherry trees reacting positively in double-antibody sandwich enzyme-linked immunosorbent assay (DASELISA) for PNRSV are shown in purple triangles and circles, respectively. Healthy sweet and sour cherry trees are in pale orange and orange, respectively. Sour cherry trees with the two most divergent PNRSV isolates (ChrT214 and ChrT224) are indicated by yellow circles. There were no trees where disease was observed without corresponding virus detection by DASELISA. North $(\mathrm{N})$ is indicated by an arrow.
One hundred thirty-six sweet cherry trees ( $P$. avium cv. Hedelfingen) and 96 sour cherry trees (P. cerasus $\mathrm{cv}$. Montmorency) grafted onto 16 dwarfing, semidwarfing, and full vigor rootstocks were surveyed for PNRSV in 2006 and 2007 (Table 1). Thirty-eight of the 232 trees (16\%) tested were positive for PNRSV in DAS-ELISA. Absorbance values were clearly higher for infected compared to healthy leaf samples with $\mathrm{OD}_{405 \mathrm{~nm}}$ readings of $0.92 \pm 0.16$ versus $0.10 \pm 0.01$ after substrate hydrolysis for $1 \mathrm{~h}$. PDV was not detected in any of the trees tested by DASELISA.

The majority of PNRSV-infected trees $(84 \%, 32$ of 38$)$ were sour cherry, while only a few of the infected trees were sweet cherry $(16 \%, 6$ of 38), although none of the pollenizer trees were infected (Table 1). Twenty-one infected trees were identified in 2006 and 17 additional trees in 2007, suggesting an increased incidence of PNRSV in the experimental orchard over two consecutive years-likely as a result of natural virus transmission via pollen movement. Taken together, our survey data were consistent with an eightfold higher incidence of PNRSV in sour cherry (33\%,
32 of 96) than in sweet cherry (4\%, 6 of 136) (Table 1). Analysis of DAS-ELISA results indicated that cherry species $(P$. cerasus vs. $P$. avium) was the primary factor influencing PNRSV incidence $(\mathrm{df}=$ $1 ; F=31.17 ; P=0.0008)$. Rootstock (df $=$ $7 ; F=1.04 ; P=0.4788)$ and cultivar $\times$ rootstock interaction $(\mathrm{df}=7 ; F=1.02 ; P=$ 0.4186) were not significant.

Analysis of the spatial distribution of PNRSV-infected trees using the threedimensional contour mapping feature of Sigmaplot indicated a clustering of the infected trees in close proximity to the five sour cherry trees that exhibited shock symptoms at the beginning of the survey (Fig. 2). Infected trees clustered in the southwest corner (rows 1 to 2 , trees 2 to 20), north-central area (rows 1 to 3 , trees 36 to 52), and northeast corner (rows 2 to 4 , trees 54 to 61 ) of the orchard. Infected sour cherry trees were dispersed throughout the orchard, whereas sweet cherry trees were located in the north-central area (rows 1 to 4 , trees 36 to 54). These results were consistent with a short distance spread of PNRSV within the orchard, likely from the initially infected, symptomatic sour cherry trees to adjacent trees.

Table 1. Incidence of Prunus necrotic ringspot virus (PNRSV) in cherry trees in an experimental orchard at the Research North Farm, NYSAES in Geneva, NY

\begin{tabular}{|c|c|c|c|}
\hline Scion & Rootstock & Infected/tested $^{a}$ & $\%$ \\
\hline Prunus cerasus L. cv. Montmorency & $\begin{array}{l}\text { Gisela } 3 \\
\text { Gisela } 5 \\
\text { Gisela } 6 \\
\text { Gisela } 7 \\
\text { Gisela } 195 / 20 \\
\text { Weiroot } 010 \\
\text { Weiroot } 013 \\
\text { Weiroot } 053 \\
\text { Weiroot } 072 \\
\text { Weiroot } 158 \\
\text { Tabel Edabriz } \\
\text { Mahaleb } \\
\text { Subtotal }\end{array}$ & $\begin{array}{l}1 / 8 \\
1 / 8 \\
5 / 8 \\
3 / 8 \\
1 / 8 \\
1 / 8 \\
2 / 8 \\
0 / 8 \\
5 / 9 \\
5 / 8 \\
4 / 8 \\
4 / 7 \\
32 / 96\end{array}$ & $\begin{array}{c}12 \\
12 \\
63 \\
63 \\
38 \\
13 \\
13 \\
25 \\
0 \\
0 \\
56 \\
63 \\
50 \\
57 \\
33\end{array}$ \\
\hline Prunus avium L. cv. Hedelfingen & $\begin{array}{l}\text { Gisela } 3 \\
\text { Gisela } 4 \\
\text { Gisela } 5 \\
\text { Gisela } 6 \\
\text { Gisela } 7 \\
\text { Gisela } 195 / 20 \\
\text { Weiroot } 010 \\
\text { Weiroot } 013 \\
\text { Weiroot } 053 \\
\text { Weiroot } 072 \\
\text { Weiroot } 158 \\
\text { Tabel Edabriz } \\
\text { Mahaleb } \\
\text { P. avium Mazzard } \\
\text { P-HL-A } \\
\text { P50 } \\
\text { Subtotal }\end{array}$ & $\begin{array}{l}0 / 8 \\
0 / 4 \\
0 / 8 \\
0 / 8 \\
1 / 8 \\
0 / 8 \\
0 / 8 \\
0 / 8 \\
0 / 8 \\
0 / 8 \\
1 / 8 \\
0 / 8 \\
0 / 7 \\
0 / 8 \\
1 / 2 \\
3 / 7 \\
6 / 116\end{array}$ & $\begin{array}{c}0 \\
0 \\
0 \\
0 \\
13 \\
0 \\
0 \\
0 \\
0 \\
0 \\
13 \\
0 \\
0 \\
0 \\
50 \\
43 \\
5\end{array}$ \\
\hline $\begin{array}{r}\text { Prunus avium L. pollenizer Black Gold } \\
\text { Emperor Francis } \\
\text { Vandalay }\end{array}$ & $\begin{array}{l}\text { Mahaleb/Mazzard } \\
\text { Mahaleb } \\
\text { nd } \\
\text { Subtotal } \\
\text { Total }\end{array}$ & $\begin{array}{c}0 / 13 \\
0 / 1 \\
0 / 6 \\
0 / 20 \\
38 / 232\end{array}$ & $\begin{array}{c}0 \\
0 \\
0 \\
0 \\
16\end{array}$ \\
\hline
\end{tabular}

${ }^{a}$ Data represent the number of trees infected by PNRSV as shown by double-antibody sandwich enzyme-linked immunosorbent assay and reverse transcription-polymerase chain reaction over the total number of trees tested in 2006 and 2007. nd: not determined. 
Latent infection was observed for most of the infected trees $(87 \%, 33$ of 38$)$, with a few sour cherry trees $(13 \%, 5$ of 38$)$ exhibiting shock symptoms or with severely reduced vigor (Fig. 1C). PNRSVinfected cherry trees were grafted onto rootstocks Gisela 3, Gisela 5, Gisela 6, Gisela 7, Gisela 195/20, P. cerasus L. (Tabel Edabriz), P. cerasus L. (Weiroot 10, 13, 72, and 158), P. mahaleb L. (Mahaleb), P50, and P-HL-A (Table 1). P. cerasus cv. Montmorency grafted onto P. cerasus L. Weiroot 53 remained PNRSV-free throughout the survey.

The CP genes of a subset of 23 PNRSV isolates (17 from sour cherry trees and six from sweet cherry trees) from the 2007 survey were characterized by RT-PCR. For each of the 23 isolates, a DNA amplicon of the expected size (approximately $675 \mathrm{bp}$ in length) was obtained from total RNA of infected leaf tissue (Fig. 3). As expected, no PNRSV DNA product was amplified from total RNA of healthy trees; however, a 183-bp-long fragment corresponding to the plant internal control $\mathrm{Rbcl}$ was obtained (Fig. 3).

The CP gene amplicons obtained by RTPCR from 17 PNRSV isolates (13 from sour cherry trees and four from sweet cherry trees) were sequenced. Identical nucleotide sequences were obtained for the majority $(59 \%, 10$ of 17$)$ of the isolates characterized (ChrT2, ChrT5, ChrT6, ChrT8, ChrT24, ChrT42, ChrT60, ChrT82, ChrT208, and ChrT225), suggesting a population structure with one predominant molecular variant. The remaining isolates (41\%, 7 of 17) corresponded to six minor molecular variants, one for isolates ChrT77 and ChrT133, and one for each of the following isolates: ChrT43, ChrT50, ChrT54, ChrT214, and ChrT224. Nucleotide sequences of PNRSV isolates from sour and sweet cherry that were unique were deposited in GenBank with accession numbers FJ213730 to FJ231738.

The PNRSV isolates sequenced in this study each had a 675-bp-long CP gene with sequence identity ranging from 97 to $100 \%$ at the nucleotide level and from 98.2 to $100 \%$ at the amino acid level. Interestingly, the $\mathrm{CP}$ gene of all isolates, except ChrT214 and ChrT224 (88\%, 15 of 17), had higher nucleotide and amino acid (99.6 to $100 \%$ ) sequence identities. Isolates ChrT214 and ChrT224 were slightly more divergent, with 97 to $97.3 \%$ and 97.2 to $99.6 \%$ sequence identity at the nucleic acid level, respectively. However, their deduced $\mathrm{CP}$ amino acid sequence was highly similar (98.2 to $98.7 \%$ for ChrT214 and 99.1 to $99.6 \%$ for ChrT224) to that of the other PNRSV isolates, even at the Nterminus where most of the variability is contained $(3,4,7,11,14,20,30,32)$. Isolates ChrT214 and ChrT224 were from two sour cherry trees (trees 60 and 61 in rows 4 and 3 , respectively) located in the northeast corner of the orchard (Fig. 2).

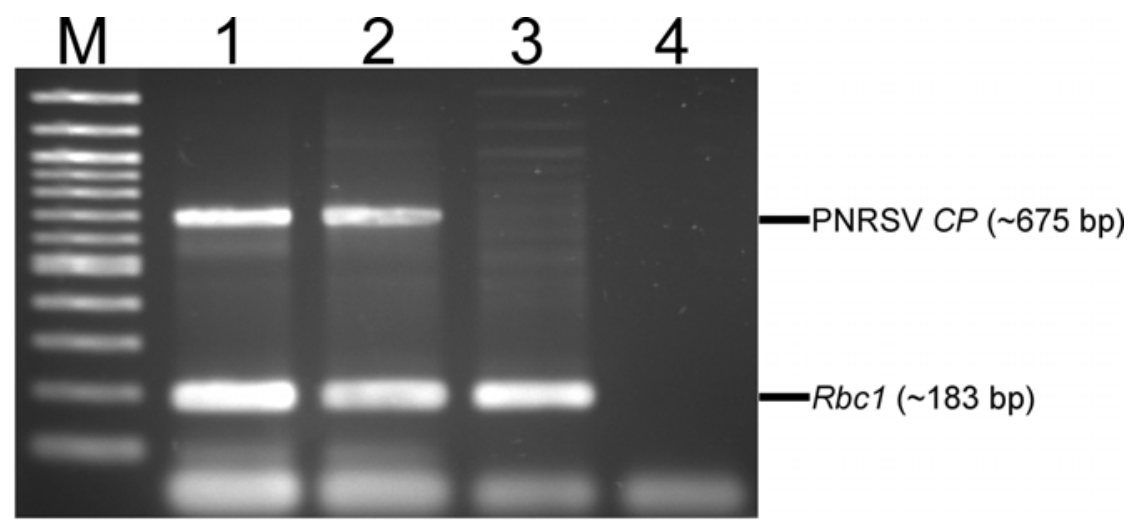

Fig. 3. Agarose gel analysis of DNA amplicons obtained by multiplex reverse transcriptionpolymerase chain reaction (RT-PCR). Total RNA extracted from leaves of sour cherry trees was used, along with primer pairs specific to the Prunus necrotic ringspot virus (PNRSV) coat protein gene and the Prunus Rbcl gene. Lanes 1-2: trees 1.28 and 2.52 infected by PNRSV, respectively; lane 3: healthy tree; lane 4: RT-PCR control lacking total plant RNA; lane M: 100-bp DNA size standard (Promega). PNRSV coat protein gene amplicon is shown at $\sim 675 \mathrm{bp}$ and the $R b c 1$ amplicon at $\sim 183 \mathrm{bp}$.

Table 2. List of Prunus necrotic ringspot virus (PNRSV) isolates used in this study to determine phylogenetic relationships

\begin{tabular}{|c|c|c|c|}
\hline Host & Isolates & GenBank accession no. & Country \\
\hline \multirow[t]{18}{*}{ Sour cherry } & ChrIt.mrs 1 & AJ133209 & Italy \\
\hline & PS $7 / 11$ & AF170161 & Czech Republic \\
\hline & PS $7 / 12$ & AF170162 & Czech Republic \\
\hline & UN & AF170163 & Czech Republic \\
\hline & PS 7/5a & AF170166 & Czech Republic \\
\hline & NRSiz6 & AF332615 & Poland \\
\hline & NRSiz8 & AF332617 & Poland \\
\hline & NRSiz9 & AF332618 & Poland \\
\hline & JW & DQ983491 & Poland \\
\hline & Mk & EU368738 & Poland \\
\hline & KU & AY037791 & Slovakia \\
\hline & NT & AY037790 & Slovakia \\
\hline & ChrT2 & This study & USA \\
\hline & ChrT50 & This study & USA \\
\hline & ChrT54 & This study & USA \\
\hline & ChrT77 & This study & USA \\
\hline & ChrT214 & This study & USA \\
\hline & ChrT224 & This study & USA \\
\hline \multirow[t]{18}{*}{ Sweet cherry } & ChrC1.cor1 & EF565248 & Chile \\
\hline & ChrC1.bin 1 & EF565249 & Chile \\
\hline & ChrC1.swe1 & EF565250 & Chile \\
\hline & ChrC1.roy1 & EF565251 & Chile \\
\hline & $1 / 13$ & AF170156 & Czech Republic \\
\hline & $21 / 1$ & AF170157 & Czech Republic \\
\hline & PS $12 / 16$ & AF170158 & Czech Republic \\
\hline & PS $14 / 22$ & AF170159 & Czech Republic \\
\hline & $4 / 8$ & AF170165 & Czech Republic \\
\hline & $7 / 20$ & AF170164 & Czech Republic \\
\hline & ChrIt.lam1 & AJ133203 & Italy \\
\hline & ChrIt.bla1 & AJ133210 & Italy \\
\hline & NRSiz1 & AF332612 & Poland \\
\hline & $\mathrm{cz} 2$ & DQ983494 & Poland \\
\hline & SW6 & AF013287 & USA \\
\hline & ChrT42 & This study & USA \\
\hline & ChrT43 & This study & USA \\
\hline & ChrT133 & This study & USA \\
\hline Wild cherry & Palampur & AM920668 & India \\
\hline Prunus mahaleb & PV96 & S78312 & Germany \\
\hline Flowering cherry & Beijing & DQ300178 & P.R. China \\
\hline \multirow[t]{4}{*}{ Apricot } & AprIt.cafl1 & AJ133199 & Italy \\
\hline & AprIt.nap1 & AJ133200 & Italy \\
\hline & AprIt.try1 & AJ133201 & Italy \\
\hline & $\mathrm{I}-9$ & DQ983493 & Poland \\
\hline \multirow[t]{3}{*}{ Nectarine } & NctSp.mur1 & AJ133208 & Spain \\
\hline & NctCl.ear1 & EF565252 & Chile \\
\hline & Nct.avg1 & EF565253 & Chile \\
\hline \multirow[t]{4}{*}{ Peach } & PchIt.may1 & AJ133205 & Italy \\
\hline & PchTu.unk1 & AJ133206 & Tunisia \\
\hline & PchIt.mry1 & AJ133207 & Italy \\
\hline & & & (Continued on next page) \\
\hline
\end{tabular}


A multiple sequence alignment of the full-length CP gene of 39 PNRSV isolates from cherry (Table 2), including those characterized in this study, indicated 88.3 to $100 \%$ and 90.2 to $100 \%$ sequence identity at the nucleotide and amino acid levels, respectively. This percentage was slightly lower (87.7 to $100 \%$ at the nucleotide level and 88 to $100 \%$ at the amino acid level) when the nucleotide sequences of the CP gene of 101 PNRSV isolates from Prunus and non-Prunus species (Table 2) were compared.

Phylogenetic analyses of the full-length $\mathrm{CP}$ gene sequence of PNRSV isolates from diverse hosts and various geographic origins indicated a clustering of cherry isolates from New York (675 bp) into the predominant group PV-96 together with other isolates (675 to $681 \mathrm{bp}$ ) from sour cherry, sweet cherry, peach, apricot, nectarine, plum, almond, and apple from Australia, Europe, South America, and the United States (Fig. 4). The same clustering of PNRSV isolates was also observed when phylogroups were obtained from the deduced 224 to $226 \mathrm{CP}$ amino acid sequences (data not shown). Furthermore, phylogenetic analyses did not indicate a clear relationship between genetic variability of PNRSV isolates and their geographical origin (Fig. 4). Similarly, no relationship was found between genetic variability and host genotype (Fig. 4). Our data on phylogenetic relationships confirmed previous reports $(3,4,7,12,32,34)$. Finally, PNRSV isolate ChrT214 was suspected to have resulted from recombination events,

Table 2. (Continued from previous page)

\begin{tabular}{|c|c|c|c|}
\hline Host & Isolates & GenBank accession no. & Country \\
\hline & Unknown1 & AM408909 & India \\
\hline & Unknown2 & AM408910 & India \\
\hline & PchCl.pom1 & EF565254 & Chile \\
\hline & PchCl.loa1 & EF565255 & Chile \\
\hline & PchCl.loa2 & EF565256 & Chile \\
\hline & PchCl.ric1 & EF565257 & Chile \\
\hline & PchCl.aug1 & EF565258 & Chile \\
\hline & PchCl.sum1 & EF565259 & Chile \\
\hline & PchBr.unk1 & EF565264 & Brazil \\
\hline & PchBr.unk2 & EF565265 & Brazil \\
\hline & PchBr.unk3 & EF565266 & Brazil \\
\hline & PlmUy.ear1 & EF565268 & Uruguay \\
\hline & PchUy.jun1 & EF565269 & Uruguay \\
\hline & B56 & DQ983492 & Poland \\
\hline & PE-5 & L38823 & USA \\
\hline & $30 / 4$ & NC_004364 & USA \\
\hline \multirow[t]{17}{*}{ Plum } & NRSiz0 & AF332611 & Poland \\
\hline & NRSiz2 & AF332613 & Poland \\
\hline & NRSiz5 & AF332614 & Poland \\
\hline & NRSiz7 & AG332616 & Poland \\
\hline & PlmAl.unk1 & AJ133211 & Albania \\
\hline & PlmIt.Clf1 & AJ133212 & Italy \\
\hline & PlmIt.mrb1 & AJ133213 & Italy \\
\hline & PlmCl.mrb1 & EF565260 & Chile \\
\hline & PlmCl.bla1 & EF565261 & Chile \\
\hline & PlmCl.fri1 & EF565262 & Chile \\
\hline & PlmCl.dag1 & EF565263 & Chile \\
\hline & PL38 & EU368737 & Italy \\
\hline & PlmUy.go11 & EF565267 & Uruguay \\
\hline & B1 & DQ983495 & Poland \\
\hline & U0 & DQ983496 & Poland \\
\hline & Emp & DQ983499 & Poland \\
\hline & Prune & AF013286 & USA \\
\hline \multirow[t]{6}{*}{ Almond } & Mission & AF013285 & USA \\
\hline & AlmIt.pre1 & AJ133202 & Italy \\
\hline & AlmIt.cor1 & AJ133204 & Italy \\
\hline & AlmCl.car1 & EF565247 & Chile \\
\hline & AL1 & EU368735 & Australia \\
\hline & AL17 & EU368736 & Italy \\
\hline \multirow[t]{4}{*}{ Apple } & Unknown1 & AM419814 & India \\
\hline & Unknown2 & AM491772 & India \\
\hline & Unknown3 & AM931161 & India \\
\hline & PV32 & Y07568 & Spain \\
\hline Pelargonium & Pa1 & AJ969110 & India \\
\hline \multirow[t]{8}{*}{ Rose } & Yunnan & AY684271 & P.R. China \\
\hline & RM-2 & AY948440 & India \\
\hline & RM-5 & AY 948441 & India \\
\hline & E260 & AJ619958 & India \\
\hline & Unknown & AJ969095 & India \\
\hline & I-23 & DQ003584 & Poland \\
\hline & I1 & DQ983497 & Poland \\
\hline & 143 & DQ983498 & Poland \\
\hline
\end{tabular}

based upon multiple nucleotide sequence alignments and phylogenetic analyses (Fig. 4). However, SISCAN analysis (9) did not provide strong support for recombination within the CP gene of isolate ChrT214 (data not shown).

\section{DISCUSSION}

The incidence of PNRSV was determined by visual symptom monitoring, DAS-ELISA, and RT-PCR in an experimental cherry orchard in which a few trees initially exhibited typical shock symptoms. PNRSV was found mainly in sour cherry trees and to a lesser extent in sweet cherry trees. Latent infection occurred in the majority of infected trees, and severely reduced vigor was observed in a few sour cherry trees. Symptoms ranging from none to mild or severe are typical reactions of cherry to PNRSV infection $(1,10,11,15$, 20,24,25).

The population structure of 17 PNRSV isolates was determined by analysis and comparison of the $\mathrm{CP}$ gene sequences. It consisted of one predominant molecular variant and six minor variants. These data are in agreement with the population structure of other plant viruses (8). To the best of our knowledge, this is the first report on the population structure of PNRSV isolates within a Prunus orchard. We analyzed only a subset of the PNRSV isolates identified in the experimental cherry orchard $(50 \%$, 17 of 34) rather than the entire population given the high genetic conservation obtained. Indeed, analysis of the genetic diversity of PNRSV isolates provided insights into the limited variability within the $\mathrm{CP}$ gene at the nucleotide level $(0.000$ to 0.004), except for isolates ChrT214 (0.030 to 0.037) and ChrT224 (0.004 to 0.028). Also, phylogenetic analysis indicated a clustering of PNRSV isolates from sour and sweet cherry trees in this New York study into group PV-96, in which the majority of PNRSV isolates characterized to date cluster $(4,7,12,13)$. This is the first report on the genetic variability of PNRSV isolates from sour cherry in North America.

Although relatively limited in number, the PNRSV isolates sequenced in this study were distributed throughout the experimental orchard (data not shown). Thus, our findings on genetic variability enabled us to speculate on the introduction of the virus into the experimental orchard and its subsequent spread between trees. In spite of the fact that the source of PNRSV from which the virus was introduced into the experimental cherry orchard is unclear, only a few trees $(16 \%, 38$ of 232) were infected, suggesting that the virus was likely not disseminated by grafting. If grafting were involved, it would have been reasonable to expect a higher number of infected trees. Also, in this case, infection would likely have been detected earlier, instead of 8 years postplanting. Rather, our 
findings appear to suggest that pollen movement may account for the introduction of PNRSV into the experimental orchard. If pollen movement was responsible, it is likely that the pollen of the virus source host was highly compatible with $P$. cerasus cv. Montmorency since sour cherry trees were predominantly infected. Furthermore, the extremely high nucleotide sequence identity ( 99.6 to $100 \%)$ within the $\mathrm{CP}$ gene of most of the isolates (88\%, 15 of 17) characterized was consistent with the introduction of a single PNRSV strain. Therefore, we hypothesize that introduction and dissemination of that strain into the experimental cherry orchard occurred through pollen flow from infected cultivated or wild cherry trees grown in the vicinity of the experimental orchard.

Introduction of PNRSV could have been a single event and, once infection of a few cherry trees (mainly sour cherry) had occurred, the virus could have subsequently continued spreading within the orchard by pollen transfer. Another possibility is that the virus may have been introduced into the experimental orchard by successive, independent pollen transfers. Regardless of the sequence of pollen transfer events from outside sources, PNRSV was introduced into the experimental cherry orchard mainly from a single virus source. The fact that the CP gene sequence of isolates ChrT214 and ChrT224 was slightly divergent at the nucleotide level compared to the other 15 PNRSV isolates characterized in this study suggests that secondary virus sources may exist within the vicinity of the northeast corner of the experimental orchard.

In this study, PNRSV was found to mainly infect sour cherry trees and to a lesser extent sweet cherry trees. These findings are consistent with a slower rate of PNRSV spread in sweet relative to sour cherry, as reported previously in New York orchards (10). There are at least three plausible explanations for the higher incidence of PNRSV in sour cherry despite the presence of more sweet cherry trees within our experimental orchard. These include potential differences between cherry genotypes in terms of virus susceptibility, flowering phenology, and pollen biology. Since differential susceptibility to PNRSV between sweet and sour cherry is not known (25), flower phenology and pollen biology could account for the higher incidence of PNRSV in sour cherry. Sweet cherry is out-crossing while sour cherry is usually self-pollinating (15). Thus, sweet cherry pollen must come from another compatible cultivar, and a high degree of bee activity on and between sweet cherry trees is required to adequately pollinate the crop during bloom. Pollination of sweet cherry was achieved in this way in the experimental orchard, and sweet cherry production was high throughout the survey for

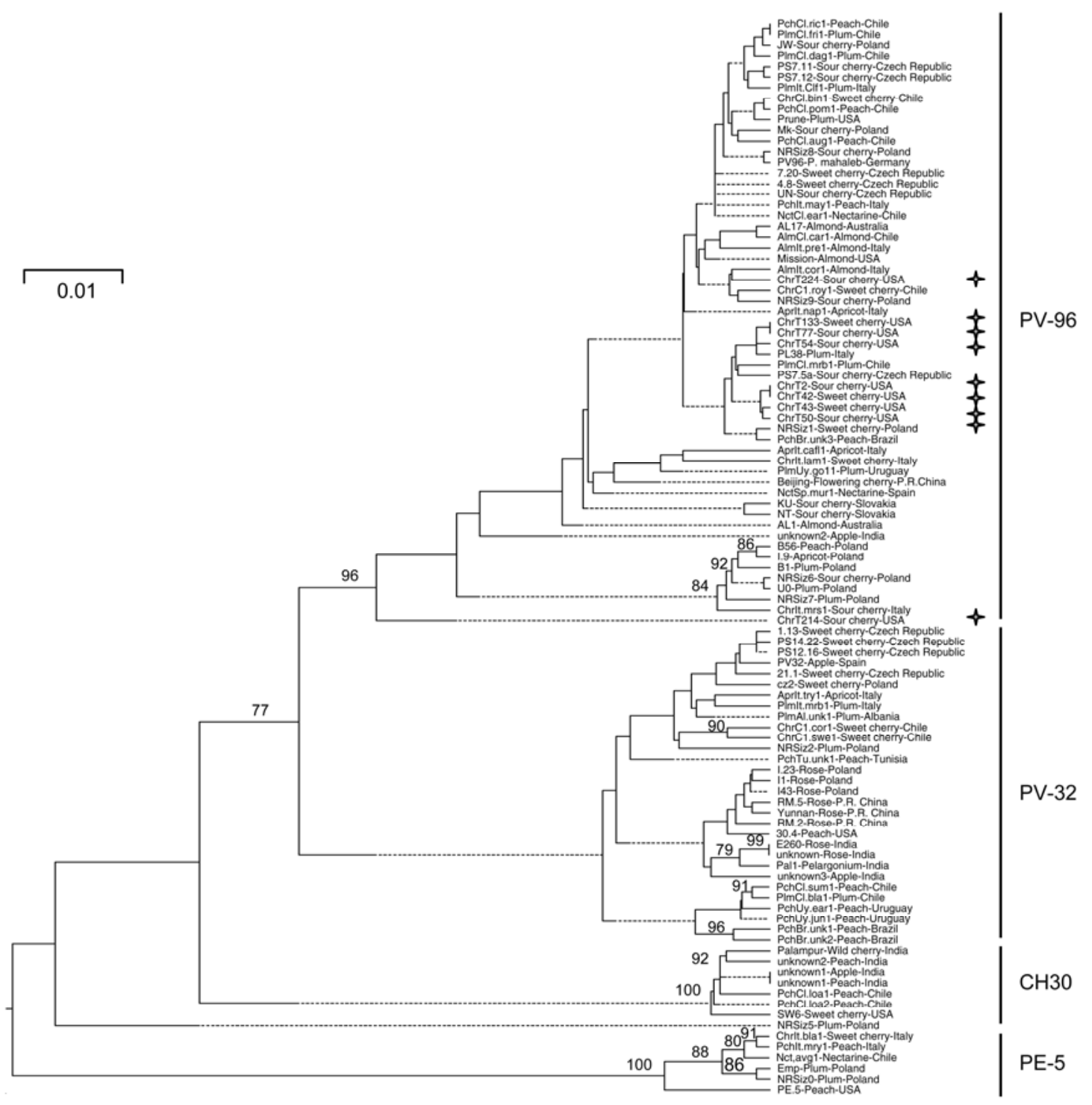

Fig. 4. Phylogenetic tree reconstructed from complete nucleotide sequence of Prunus necrotic ringspot virus (PNRSV) coat protein gene by the neighborjoining method with 1,000 bootstrap replicates. Branch lengths represent phylogenetic distances determined by distance matrices of nucleotide sequences. Numbers above critical branches are significant bootstrap values $(>75 \%)$. Scale bar represents a relative genetic distance of 0.01 . For each sequence, corresponding isolate and country of origin are indicated. PNRSV isolates sequenced in this study are indicated by stars. 
PNRSV (R. L. Andersen, unpublished). Sour and sweet cherry do not readily pollinate each other, although cross-pollination can occur to a limited extent (15). Therefore, if PNRSV had infected sour cherry first in our experimental orchard, it is conceivable that pollen production and movement from PNRSV-infected P. cerasus cv. Montmorency occurred more readily within sour cherry trees than from sour cherry to sweet cherry trees. Furthermore, although sweet cherry trees start blooming before sour cherry trees, bloom times often overlap. However, if pollen movement in sour cherry trees was not in synchrony with stigma development in $P$. avium $\mathrm{cv}$. Hedelfingen, this may have also favored PNRSV movement within sour cherries and hindered movement from sour cherry to sweet cherry trees. As a consequence of both of these scenarios, more sour cherry trees would be expected to become infected with PNRSV, explaining the higher incidence of the virus among sour cherry trees seen in this study.

Our findings on the genetic variability of PNRSV isolates provide further evidence of pollen movement and virus spread within the experimental orchard. The nucleotide sequences of the $\mathrm{CP}$ gene of several isolates from sour cherry (ChrT2, ChrT5, ChrT6, ChrT8, ChrT24, ChrT42, ChrT60, ChrT82, and ChrT225) and isolate ChrT208 from sweet cherry are identical, suggesting movement of a single PNRSV isolate from sour to sweet cherry trees. Similarly, the nucleotide sequences of the CP gene of isolates ChrT77 from sour cherry and ChrT133 from sweet cherry are identical. These data are consistent with limited pollen-mediated transfer of PNRSV from sour cherry to sweet cherry trees.

Previously, the susceptibility of cherry rootstocks to PNRSV was investigated by graft-inoculation of $P$. avium cv. Bing trees $(16,18)$. The following rootstocks were classified as sensitive: Gisela 7, Gisela 195/20, and Weiroot 10, 13, and 53. Gisela 3, Gisela 5, Gisela 6, Tabel Edabriz, Mahaleb, and Weiroot 72 and 158 were classified as tolerant $(16,18)$. Tree reaction to graft-inoculation of PNRSV was evaluated based on symptom severity, i.e., gum exudation at the graft union, inhibition of lateral shoot elongation, foliar symptoms, and rapidity of tree death $(16,18)$. Our survey data indicate moderate to high infection rates of $P$. cerasus cv. Montmorency grafted onto Gisela 6, Gisela 7, Tabel Edabriz, Mahaleb, and Weiroot 72 and 158, and low infection rates of trees grafted onto Gisela 3, Gisela 5, and Weiroot 10, 13, and 53. Although our work did not focus on cherry rootstock susceptibility to PNRSV, there seems to be a differential reaction of cherry trees to PNRSV infection following graft-inoculation $(16,18)$ and pollen transfer (this study) for Gisela 6, Gisela 195/20, Tabel Edabriz, Mahaleb, and Weiroot 10, 53, 72, and 158. One plausible explanation for this apparent discrepancy is the fact that cherry tree reaction to graft-inoculation in previous studies $(16,18)$ was scored based on disease severity, whereas in this study, reaction to pollen infection was evaluated based on monitoring symptom development and PNRSV detection in the canopy by DAS-ELISA and RT-PCR. Differences in virus strains, environmental conditions, and scion genotype $(P$. avium cv. Bing versus $P$. cerasus cv. Montmorency) could also account for these differential reactions of scions grafted onto different rootstocks (16 and 18 versus our study).

Host resistance would be an ideal strategy to manage PNRSV. Since resistance to PNRSV is not known in Prunus spp., including sour and sweet cherry (20,25, 28,33 ), the foremost control strategy in an orchard is exclusion. This approach consists of identifying infected trees at a very early stage of infection followed by diligent removal and destruction in order to limit secondary virus spread to healthy trees or to new orchards. Since latent infection is common for PNRSV, virus spread can readily occur through pollen transmission even when trees are asymptomatic. Therefore, until resistant trees can be developed, surveying cherry orchards by DAS-ELISA and RT-PCR, as shown in our study, is critical for optimal PNRSV detection and subsequent elimination of infected trees.

\section{ACKNOWLEDGMENTS}

We are grateful to Joanna McDonald, Rosemary Cox, Pat Marsella-Herrick, Eric Rockefeller, and Aracely Ospina for assistance with sample processing, Emmanuelle Vigne for advice with the SISCAN software, and L. M. Yepes for critically reading the manuscript. This work was partially supported by state, federal, and institutional funds appropriated to the New York State Agricultural Experiment Station, Cornell University.

\section{LITERATURE CITED}

1. Allen, W. R. 1963. Comparison of strains of Prunus necrotic ringspot and prune dwarf viruses with viruses in the Pfeffinger (rasp leaf) type. Phytopathology 53:1436-1442.

2. Allen, W. R. 1963. Serological and physicochemical comparison between viruses of the Prunus necrotic ringspot and Pfeffinger (rasp leaf) types. Phytopathology 54:455-459.

3. Aparicio, F., Myrta, A., Di Terlizzi, B., and Pállas, V. 1999. Molecular variability among isolates of Prunus necrotic ringspot virus from different Prunus spp. Phytopathology 89:991999.

4. Aparicio, F., and Pallàs, V. 2002. The molecular variability analysis of the RNA3 of fifteen isolates of Prunus necrotic ringspot virus sheds light on the minimal requirements for the synthesis of its genomic RNA. Virus Genes 25:75-84.

5. Bol, J. F. 2005. Replication of alfamo- and ilarviruses: Role of the coat protein. Annu. Rev. Phytopathol. 43:39-62.

6. Crosslin, J. M., and Mink, G. I. 1992. Biophysical differences among Prunus necrotic ringspot ilarviruses. Phytopathology 82:200206.

7. Fiore, N., Fajardo, T. V. M., Podan, S., Her- ranz, M. C., Aparicio, F., Montealegre, J. Elena, S. F., Pallás, V., and Sánchez-Navarro, J. 2008. Genetic diversity of the movement and coat protein genes of South American isolates of Prunus necrotic ringspot virus. Arch. Virol. 153:909-919.

8. Garcia-Arenal, F., Fraile, A., and Malpica, J. M. 2001. Variability and genetic structure of plant virus populations. Annu. Rev. Phytopathol. 39:157-186

9. Gibbs, M. J., Armstrong, J. S., and Gibbs, A. J. 2000. Sister-scanning: A monte carlo procedure for assessing signals in recombinant sequences. Bioinformatics 16:573-582.

10. Gilmer, R. M. 1961. The frequency of necrotic ring spot, sour cherry yellows and green ring mottle viruses in naturally infected sweet and sour cherry orchard trees. Plant Dis. Rep. 45:612-615.

11. Gilmer, R. M., and Kamalsky, L. R. 1962. The incidence of necrotic ring spot and sour cherry yellows viruses in commercial Mazzard and Mahaleb cherry rootstocks. Plant Dis. Rep. 46:583-585.

12. Glasa, M., Betinová, E., Kúdela, O., and Subr, Z. 2002. Biological and molecular characterization of Prunus necrotic ringspot virus isolates and possible approaches to their phylogenetic typing. Ann. Appl. Biol. 140:279-283.

13. Hammond, R. W. 2003. Phylogeny isolates of Prunus necrotic ringspot virus from the ilarvirus ringtest and identification of group-specific features. Arch. Virol. 148:276-278.

14. Hammond, R. W., and Crosslin, J. M. 1998. Virulence and molecular polymorphism of Prunus necrotic ringspot virus isolates. J. Gen. Virol. 79:1815-1823.

15. Hauck, N. R., Yamane, H., Tao, R., and Iezzoni, A. F. 2002. Self-compatibility and incompatibility in tetraploid sour cherry (Prunus cerasus L.). Sex Plant Reprod. 15:39-46.

16. Howell, W. E., and Lang, G. A. 2001. Virus sensitivity of new sweet cherry rootstocks. Compact Fruit Tree 34:78-80. http:///www. virtualorchard.net/idfta/cft/2001/july/page78. pdf.

17. Howell, W. E., and Mink, G. I. 1988. Natural spread of cherry rugose mosaic disease and two Prunus necrotic ringspot virus biotypes in a central Washington sweet cherry orchard. Plant Dis. 72:636-640.

18. Lang, G., and Howell, W. 2001. Lethal sensitivity of some new cherry rootstocks to pollenborne viruses. Acta Hortic. 557:151-154.

19. Milne, J. R., and Walter, G. H. 2003. The coincidence of thrips and dispersed pollen in PNRSV-infected stonefruit orchards - A precondition for thrips-mediated transmission via infected pollen. Ann. Appl. Biol. 142:291-298.

20. Mink, G. I. 1992. Prunus necrotic ringspot virus. Pages 335-356 in: Plant Diseases of International Importance. Vol. III. J. Kumer, H. S. Chaube, U. S. Singh, and A. N. Mukhadpadhyay, eds. Prentice Hall, New York.

21. Mink, G. I., Howell, W. E., Cole, A., and Regev, S. 1987. Three serogroups of Prunus necrotic ringspot virus biotypes from rugose mosaic-disease sweet cherry trees in Washington. Plant Dis. 68:207-210.

22. Moury, B., Cardin, L., Onesto, J.-P., Candresse, T., and Poupet, A. 2001. Survey of Prunus necrotic ringspot virus in rose and its variability in rose and Prunus spp. Phytopathology 91:84-91.

23. Myrta, A., Di Terlizzi, B., Boscia, D., Choueri, E., Gatt, M., Gavriel, I., Caglayan, K., Varveri, C., Zeramdini, H., Aparicio, D., Pallas, V., and Savino, V. 2001. Serological characterization of Mediterranean Prunus necrotic ringspot virus isolates. J. Plant Pathol. 83:45-49.

24. Parker, K. G., Brase, K. D., Schmid, G. Barksdale, T. H., and Allen, W. R. 1959. Influence of ring spot virus on growth and yield of sour cherry. Plant Dis. Rep. 43:380-384. 
25. Pscheidt, J. W. 2007. Cherry - Prunus necrotic ringspot. Online guide to Plant Disease Control, Oregon State University Extension. http:// ipmnet.org/plant-disease/factsheet.cfm?Record ID $=293 \&$ rec_type $=$ disease.

26. Saitou, N., and Nei, M. 1987. The neighborjoining method: A new method for reconstructing phylogenetic trees. Mol. Biol. Evol. 4:406425.

27. Sánchez-Navarro, J. A., Aparicio, F., Herranz, M. C., Minafra, A., Myrta, A., and Pallás, V. 2005. Simultaneous detection and identification of eight stone fruit viruses by one-step RTPCR. Eur. J. Plant Pathol. 111:77-84.

28. Scott, S. W., Barnett, O. W., and Burrows, P. M. 1989. Incidence of Prunus necrotic ringspot virus in selected peach orchards of South Carolina. Plant Dis. 73:913-916.
29. Scott, S. W., Zimmermann, M. T., Ge, X., and MacKenzie, D. J. 1998. The coat protein and putative movement proteins of isolates of Prunus necrotic ringspot virus from different host species and geographic origins are extensively conserved. Eur. J. Plant Pathol. 104:155161.

30. Spiegel, S., Tam, Y., Maslenin, L., Kölber, M., Nemeth, M., and Rosner, A. 1999. Typing Prunus necrotic ringspot virus isolates by serology and restriction endonuclease analysis of PCR products. Ann. Appl. Biol. 135:395-400

31. Thompson, J. D., Higgins, D. J., and Gibson, T. J. 1994. CLUSTAL W: Improving the sensitivity of progressive multiple sequence alignment through sequence weighting, positionspecific gap penalties and weight matrix choice. Nucleic Acids Res. 22:4673-4680.

32. Ulubas, C., and Ertunc, F. 2004. RT-PCR detection and molecular characterization of Prunus necrotic ringspot virus isolates occurring in Turkey. J. Phytopathol. 152:498-502.

33. Uyemoto, J. K., and Scott, S. W. 1992. Important diseases of Prunus caused by viruses and other graft-transmissible pathogens in California and South Carolina. Plant Dis. 76:5-11.

34. Vaskavám, D., Petrzik, K., and Karesová 2000. Variability and molecular typing of the woody-tree infecting prunus necrotic ringspot ilarvirus. Arch. Virol. 145:699-709.

35. Wong, S.-M., Horst, R. K., and Langhans, R. W. 1988. Symptomatology and occurrence of apple mosaic and prunus necrotic ringspot viruses on rose in New York. Acta Hortic. 234:437-450. 